\title{
A comparison of alcoholic pancreatitis in rat and man
}

\author{
H. SARLES, G. LEBREUIL, F. TASSO, C. FIGARELLA, F. CLEMENTE, \\ M. A. DEVAUX, B. FAGONDE, AND H. PAYAN
}

From the Unité de Recherches de Pathologie Digestive, Marseille, France

SUMMARY Acute ethanol intoxication was studied in 38 Wistar rats, 18 on a balanced diet and 20 on a high fat diet, fed by gavage on $47 \%$ ethanol in a dosage of from 3 to $12 \mathrm{~g} / \mathrm{kg}$ body weight daily for periods ranging from three to 16 days. No macroscopic changes in pancreas or liver were found in any of these animals. Histological changes (venous congestion of the pancreas, the liver, and the kidneys) were found in rats given $4 \mathrm{~g}$ or more per kilogram. The only difference between the findings in rats given a balanced diet and those given a high fat diet was the development of fatty livers in the latter group.

Chronic ethanol intoxication was studied in 45 Wistar rats, on a balanced diet, which were given $20 \%$ ethanol freely for 20 to 30 months. More than half the animals developed pancreatic lesions very similar to those of human chronic pancreatitis. The pathological changes, in foci surrounded by normal pancreatic tissue, were a reduction in acini, duct multiplication (probably by neogenesis), protein plugs, sometimes calcified in the ducts and sclerosis. Samples of pancreatic juice from four animals exposed to ethanol contained significantly higher protein concentrations than samples taken from two control animals. Protein precipitates appeared spontaneously in the pancreatic juice of the animals exposed to ethanol, but not in that of the controls. These findings are very similar to those in alcoholic pancreatitis in man, which has thus been reproduced for the first time in experimental animals. Beta-cell adenomata of the islets of Langerhans were observed in four of the rats exposed to ethanol.

Different workers have assessed the effect of ethanol on the pancreas of the rat in different ways. Thus ethanol leads to a decrease in pancreatic nucleotides and adenosine monophosphate (Decloître and Lowry, 1963), a diminished incorporation of DLleucine-1-14 $\mathrm{C}$ into pancreatic protein, and reduced oxygen uptake by pancreatic tissue (Sardesai and Orten, 1968). Orrego-Matte, Navia, Feres, and Costamaillere (1969) report reduced incorporation of ${ }^{32} \mathrm{P}$ into pancreatic lipids. On the other hand, Tsuzuki, Watanabe, and Thal (1965) found that alcohol has no effect on incorporation of DLleucine-1-14 $\mathrm{C}$ into zymogen and other subcellular fractions, while Goslin, Hong, Magee, and White (1965) even concluded that alcohol increased the protease and lipase in the pancreas.

In an earlier paper (Sarles, Figarella, and Clemente, 1970), we have shown that these divergent findings were probably accounted for by the type of dietary Received for publication 2 March 1971. regime associated with the ethanol administration. Ethanol was given freely in a $20 \%$ concentration for two months to rats on a diet low in protein and reduced pancreatic amylase, chymotrypsinogen, lipase, and trypsinogen, whereas in animals fed on a high protein, high fat diet, ethanol increased the amount of the excretory enzymes in the pancreas and very probably the synthesis of these enzymes and their concentration in the zymogen granules.

Trémolieres, Carre, Scheggia, Potet, and Martin (1963) reported finding acute lesions, vascular congestion, oedema, coagulation necrosis, and fat necrosis in three out of $\mathbf{1 4}$ rats after administering $20 \%$ ethanol by gavage on one or two occasions, and more frequently when the ethanol was injected intraperitoneally. But as yet no workers have been able to reproduce in rats lesions similar to chronic pancreatitis in man.

Ultramicroscopic studies of the pancreas when rats had ingested ethanol for two months (Tasso, Clop, 
and Sarles, 1970), revealed abnormally developed phospholipid vacuoles, moderate involvement of mitochondria, and dilatation of the ergastoplasmic sacks. In addition Darle, Ekholm, and Edlund (1970) found foci of cytoplasmic degradation in animals exposed to ethanol for over 36 weeks. Similar foci of significance had been noted by Tasso et al (1970) as early as the eighth week of exposure to ethanol. However, none of these features resembles the appearances seen histologically by light microscopy (Sarles, Sarles, Camatte, Muratore, Gaini, Guien, Pastor, and Le Roy, 1965), or by electron microscopy (Tasso, 1967) in human chronic pancreatitis.

Cueto, Tajen, and Zimmerman (1967) believed that they had produced changes of chronic pancreatitis in dogs by administering $6 \mathrm{~g}$ ethanol per $\mathrm{kg}$ five times weekly for two months through a gastrostomy tube. However, Menguy, Hallenbeck, Bollman, and Grindlay (1958), discussing this work, expressed the opinion that the authors were wrong to call these lesions pancreatitis. When we ourselves gave dogs these same doses of ethanol by stomach tube for six days a week for periods ranging from five to 21 weeks, the only abnormal findings were minimal changes in the mitochondria and an increase of lysosomes (Sarles, Tasso, and Lebreuil, 1970, unpublished work). These were more pronounced in the liver than in the pancreas.

\section{Methods and Materials}

\section{ACUTE ALCOHOLIC INTOXICATION}

The animals used were Wistar CF rats. They were maintained on a balanced, commercial rat diet ' $\mathrm{N}$ ' containing $18.5 \%$ protein and $10 \%$ of the total calorie value as fat together with starch, vitamins, and mineral salts. The rats, housed in separate cages, were permitted to eat freely. In these conditions, the mean dietary consumption of a rat was $15 \mathrm{~g}$ per day. In the first 15 days water was made freely available to all animals. At the end of this period the animals either continued to receive the control diet ' $N$ ' or were allocated to test groups. One such group, chosen at random, received 3 to $9 \mathrm{ml}$ of alcohol diluted to $47 \%$ by volume once a day by gavage. A second group received an isocaloric solution of sucrose. The animals were weighed before each gavage. After the administration of ethanol, they exhibited signs of alcohol intoxication ending 10 or 15 minutes later in prostration. In our early experiments, gavage with alcohol led to many deaths. Those rats in poor condition were quickly sacrificed by a blow on the neck. The liver, pancreas, and brain were removed and placed in Bouin's solution for subsequent histological examination. It should be noted that despite the use of a semi-rigid polyethylene tube, scrutiny of the stomach sometimes revealed haemorrhagic areas which were attributed to trauma.

Eleven rats remained on a normal protein, low fat diet ('N'). Eight of these received $3 \mathrm{~g} / \mathrm{kg}$ of ethanol on three consecutive days and three rats were given sucrose. All were killed two hours after the third gavage.

Twenty rats, weighing about $200 \mathrm{~g}$ each, were randomly divided into two equal groups. Group A (10 rats) received $3 \mathrm{ml}$ ethanol which was diluted to $47 \%$ daily for seven days. For seven days thereafter the test group received $6 \mathrm{ml}$ of ethanol and $9 \mathrm{ml}$ for the next week. The alcoholic intake of the group was approximately $4 \mathrm{~g} / \mathrm{kg}, 8 \mathrm{~g} / \mathrm{kg}$, and $12 \mathrm{~g} / \mathrm{kg}$ in each of the three weeks. The control group $B$ (10 rats) received isocaloric amounts of sucrose. In the first week, all the rats gained weight and appeared normal, but though some rats receiving $6 \mathrm{ml}$ ethanol maintained weight, five had to be sacrificed. Of the remaining five receiving $9 \mathrm{ml}$ ethanol during the third week, it was necessary to kill two rats after one gavage and three rats were killed after two gavages of $9 \mathrm{ml}$ ethanol.

Twenty-five rats weighing about $200 \mathrm{~g}$ were put on a rich protein diet, ' $T$ ' (Sarles et al, 1970), which contained $34 \%$ of the calories as fat and $17 \%$ as protein; the rest was starch, vitamins, and salts. A test group of 20 rats was given $6 \mathrm{ml}$ ethanol diluted to $47 \%$ by volume (approximately $10 \mathrm{~g} / \mathrm{kg}$ ) every 48 hours and five rats were given $6 \mathrm{ml}$ of isocaloric sucrose every 48 hours. Seven rats on alcohol died and three, including one of the control group, were killed after the first gavage. Ten rats on alcohol and one control rat were killed after the second gavage. The remaining rats on alcohol and the controls were killed after the third gavage.

\section{CHRONIC ALCOHOLIC INTOXICATION}

Sixty-one Wistar rats weighing from 100 to $120 \mathrm{~g}$ at the start of the experiment were maintained on the standard ' $N$ ' diet and were divided into two groups at random. The test group, comprising 45 rats, received $20 \%$ ethanol by weight and were allowed to drink freely throughout the experimental period. The mean daily consumption of alcohol was in the region of $4 \mathrm{~g}$ per rat. The control group of 16 rats received water. The rats were housed in groups of five at a temperature of $20 \pm 1^{\circ} \mathrm{C}$. Five of the test rats and six controls were sacrificed at a mean of 20 months after beginning the experiment. Thirty months after the start, 20 of the remaining 40 rats on alcohol had died spontaneously as had four of the controls. The survivors were killed by a sharp blow on the neck. The pancreas was removed and either the proximal or distal segment, selected at random, 
was processed for histology and electron microscopy or for enzyme studies.

On fragments of the pancreas of the rats under observation for 30 months (14 on alcohol and six on water) DNA, total protein, lipase, amylase, trypsinogen, and chymotrypsinogen were measured (Sarles and Figarella, 1967). Protein and units of enzyme were expressed in terms of $\mathrm{mg}$ of $\mathbf{P}$ of the DNA. The results were assessed by the Mann-Whitney U test. (Siegel, 1956).

Pancreatic fistulae were established in four of the test rats which received alcohol and two controls, all from the 30-month group, and two samples of pancreatic juice were taken each day for one to three days. The protein content of the juice was measured by the technique of Lowry, Rosebrough, Farr, and Randall (1951).

A block of pancreatic tissue from all the animals was fixed in Bouin's fluid, embedded in paraffin, and stained with haematoxylin and eosin, Masson's trichrome stain, and Gomori's aldehyde fuchsin stain for islet cells. Two sections from each rat were examined under the light microscope except for sections from one rat in which all the pancreas was examined.

Blocks of pancreatic tissue were fixed in $2 \%$ phosphate-buffered osmium tetroxide solution (Millonig, 1961) and embedded in epoxy resin (Epon) (Luft, 1961). Tissue was taken from four rats exposed to ethanol for 20 months and 17 rats exposed for 30 months, as well as four 20 -month and six 30 -month controls. Semithin sections $1 \mu$ thick were stained with toluidine blue. Ultrathin sections were made with a glass knife in a Porter Blum microtome, doubly stained with uranyl acetate (Watson, 1958) and lead citrate (Reynolds, 1963), and examined under a Philips EM 300 electron microscope.

\section{Results}

ACUTE ETHANOL INTOXICATION

No gross changes were noted in the pancreas or liver of the 18 rats fed on a balanced diet and given 3 to $12 \mathrm{~g}$ of ethanol/ $\mathrm{kg}$ body weight. No microscopic lesions were found in the eight rats given $3 \mathrm{~g}$ per $\mathrm{kg}$ daily on three consecutive days. In the 10 rats given larger doses, the only histological lesion in the pancreas was venous congestion, which was present to an even greater degree in the liver and kidneys. No haemorrhagic necrosis or fat necrosis was present in the pancreas, nor was fatty infiltration of the liver observed. In half the animals a microvacuolar degeneration was noted in the renal convoluted tubules.

In the 20 rats exposed to ethanol while on a high fat diet no gross pancreatic lesion was visible. The only histological change in the pancreas was venous congestion, observed after the second dose of $10 \mathrm{~g}$ of ethanol per $\mathrm{kg}$. A constant finding in the liver was a predominantly centrolobular fatty infiltration sometimes accompanied by diffuse sinusoidal congestion. Haemorrhagic erosions, coagulation necrosis, and mild oedema of the submucosa were present in the stomach.

\section{CHRONIC ETHANOL INTOXICATION}

The mortality rate after 30 months' exposure to ethanol was the same in the group treated with ethanol (20/40) and in the control group (4/10).

Neither the mean weight of the animals nor the mean weight of the pancreas differed significantly in the ethanol and control groups (Table l).

The mean protein concentration in 13 samples from four animals treated with ethanol was $16 \cdot 25 \mathrm{~g} / \mathrm{l}$. (SD 6.29). In 13 samples from two control animals it was 9.09 $\mathrm{g}$ per litre (SD 5.06). This difference is significant (Student's $t$ test; $t=3.20, P<0.005$ ). Six of the 13 samples from ethanol rats contained a flocculent precipitate not present in any of the control samples. Although such precipitates generally accompanied high protein concentrations, in one instance it was associated with a concentration of $6.81 \mathrm{~g}$ of protein per litre (Table I).

The findings of the protein and enzyme content of

\begin{tabular}{lll}
\hline & Ethanol 20\% $(14$ rats $)$ & Water $(6$ rats $)$ \\
\hline Weight of animal (g) & $401(200-520)^{1}$ & $400(300-477)$ \\
Weight of pancreas $(\mathrm{g})$ & $1 \cdot 144(0 \cdot 475-1 \cdot 689)$ & $1 \cdot 332(0 \cdot 815-1 \cdot 862)$ \\
Pancreatic protein' $^{2}$ & $42(28-62)$ & $45(28-62)$ \\
Pancreatic lipase $^{2}$ & $64 \cdot 7(26 \cdot 2-127 \cdot 3)$ & $69 \cdot 4(18 \cdot 6-185 \cdot 5)$ \\
Pancreatic amylase $^{2}$ & $11 \cdot 0(6 \cdot 3-17 \cdot 9)$ & $13 \cdot 2(7 \cdot 0-25 \cdot 5)$ \\
Pancreatic trypsinogen & $0 \cdot 90(0 \cdot 45-1 \cdot 69)$ & $1 \cdot 31(0 \cdot 19-3 \cdot 62)$ \\
Pancreatic chymotrypsinogen & $7 \cdot 93(3 \cdot 52-14 \cdot 82)$ & $7 \cdot 22(2 \cdot 98-10 \cdot 23)$ \\
\hline
\end{tabular}

Table I Chronic ethanol intoxication in rats after 30 months' exposure to $20 \%$ ethanol pancreatic content in proteins and enzymes

${ }^{1}$ Mean, with the range given in parentheses.

${ }^{2}$ Both protein and enzyme content is expressed in $\mathrm{mg}$ of protein and international units of enzyme per mg of $\mathbf{P} / \mathrm{DNA}$. 
pancreas are shown in Table I. Analysis by the Mann Whitney $U$ test revealed no significant difference between the results in the animals exposed to ethanol and those in the control group.

Pancreatic lesions were found in 13 of the 20 rats exposed to $20 \%$ ethanol for 30 months (Table II) and in two of the five rats exposed for 20 months. The incidence of pathological changes seen by light microscopy was probably higher than these figures - suggest. In one rat no changes were visible in the two routine sections, but severe lesions were detected when other sections from the block were inspected. The lesions differed little from one animal to another; the outstanding characteristic was the regularity with which a group, or several groups, of lobules lying in the midst on intact lobules were involved (Fig. 1). In a single animal the entire parenchyma was implicated, with the exception of a group of acinar lobules in the head of the gland which were totally unaffected. A minute and solitary lesion, identical to those in the ethanol rats, was found on one of the 12 control rats treated for 30 months. One slide showing incipient lesions of the disease in man is illustrated for comparison in Figure 2.

The pathological changes, irrespective of their extent, were uniform in character, namely, replacement of atrophic acini by ducts surrounded by fibroinflammatory interstitial connective tissue. New duct proliferation was proportioned to acinar cell damage, which varied in severity, ranging from simple lack of cytoplasmic density, the apical pole of the cell containing vacuolar granules which stained poorly or not at all by the periodic acid Schiff technique, to replacement by fat steatosis, partial atrophy with nuclear cytoplasmic clarification, even leading to total atrophy.

As a consequence of duct proliferation atrophied acini were replaced by gland-like spaces, uniform in size, and lined with clear cuboidal or flattened epithelial cells with poorly stained nuclei. Some of the nuclei were undergoing mitosis, suggesting recent formation. Bead-like dilatations along the course of the intercalary ducts accentuated the tortuosity of these channels. These extended in parts to the interlobular ducts. The duct walls were lined with cuboidal or endothelioid epithelium with no metaplastic features. Intraductal protein precipitates were a constant feature filling the lumen of one or several duct segments and staining well with eosin or safranin. Some of these protein plugs were calcified and demonstrable by the von Kossa technique, and some showed stratification. In only one animal were intraductal protein plugs observed in the absence of acinoductal lesions (Fig. 3).

The interstitial spaces were the site of an organized fibrosis which, both perilobular and intralobular, made its appearance at an early stage and affected atrophying lobules only (Fig. 3). The epithelial growth was enveloped by collagen fibres and fibroblasts. The connective tissue was young and rich in cells; the density of its lymphocytic and plasma cell infiltrations varied from rat to rat. The tissue contained some mastocytes and free or intrahistiocytic spherical pigment deposits but no eosinophils. No changes were observed in the blood vessels and nerves.

\begin{tabular}{llll}
\hline Pancreatic Lesion & Severity of Lesion & $\begin{array}{l}\text { No. of Treated Rats }(20 \%) \\
\text { Ethanol Affected (20 rats) }\end{array}$ & No. of Controls Affected (6 rats) \\
\hline Lobular & 1 & 3 & 1 \\
& 2 & 7 & \\
Acinar atrophy & 3 & 2 & 1 \\
Ducts & 4 & 1 & 1 \\
& Subtotal & 8 & 1 \\
Fibrosis & Total $^{\mathbf{3}}$ & 5 & 1 \\
Mononuclear infiltration & Neogenesis & 13 & 1 \\
& Dilatation & 13 & 1 \\
Interstitial haemosiderosis & Protein plugs & 14 & \\
Islets of Langerhans & 2 & 9 & \\
& 1 & 8 & \\
& 2 & 2 & 1 \\
\end{tabular}

Table II Chronic ethanol intoxication in rats after 30 'months' exposure to $20 \%$ ethanol lesions in pancreas observed by light microscopy ${ }^{1}$

${ }^{1}$ Fatty degeneration of liver was noted in nine of the ethanol animals and in none of the controls.

Degree of severity is assessed as $1,2,3$, or 4 .

3 Acinar cells present in the lesions.

-No surviving acinar cells in the lesions. 


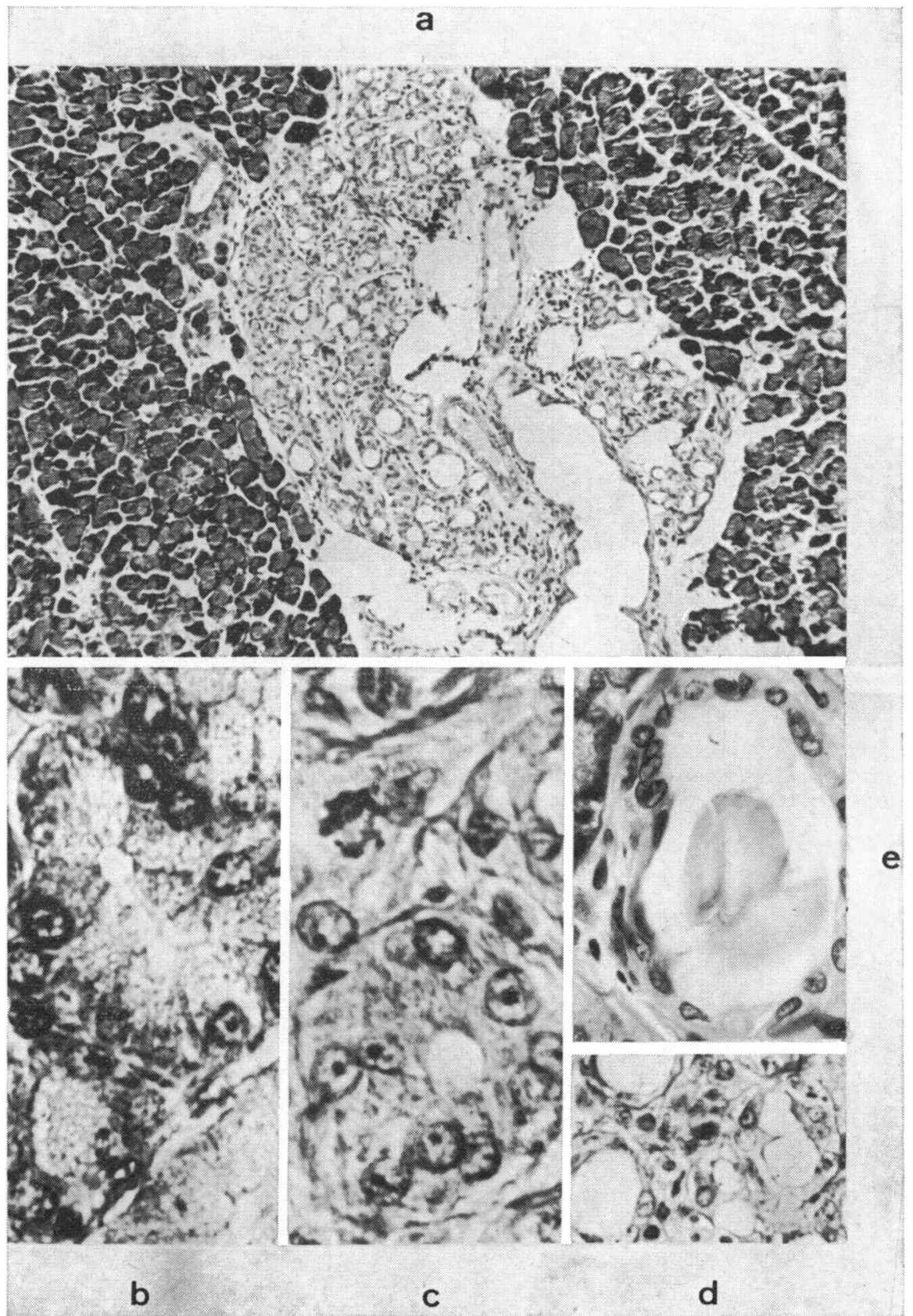

Fig. 1 Chronic ethanol pancreatitis in rat. Haematoxylin and eosin. a Lesion confined to one lobule $(\times 400)$. Distension of acini and ducts. Adjacent lobules intact. b Same lesion ( $\times$ 4,000). Slight distension of lumina of acini; no gross change in epithelial elements. c Same lesion $(\times 4,000)$. Similar appearance to $b$. Note disappearance of zymogen granules from centre of acinar cells. d Another lesion $(\times 1,600)$. Distension of ducts and flattening of duct cells. e Same lesion as $\mathrm{d}(\times 2,000)$. Distended intralobular duct containing a protein plug. 


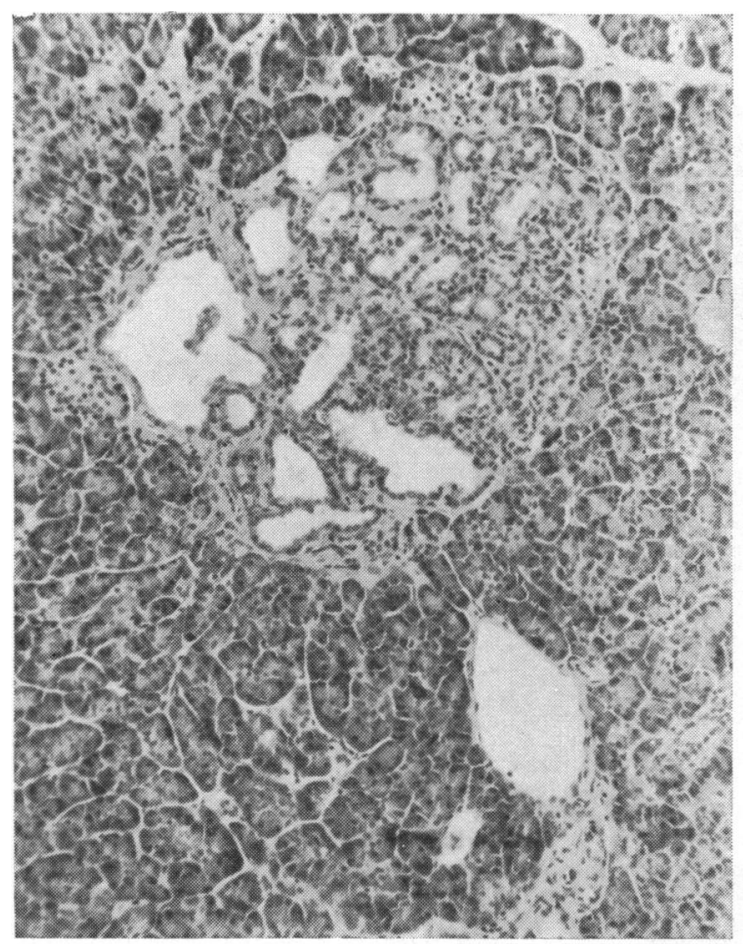

Fig. 2a.

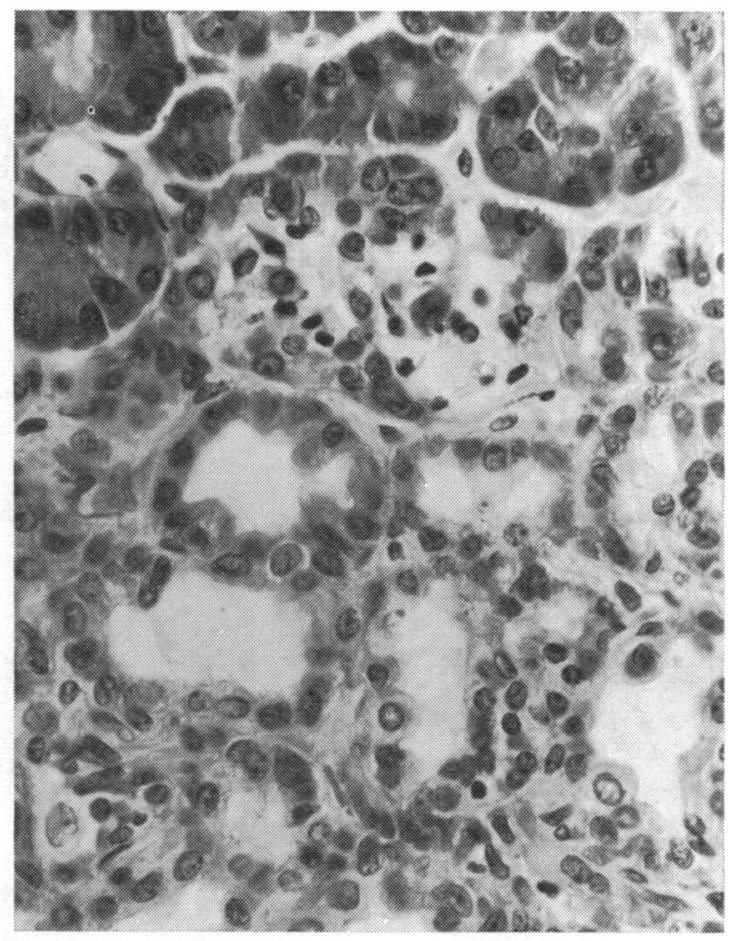

Fig. 2b.

Fig. 2 Calcifying pancreatitis in man. Haematoxylin and eosin. a Lesion localized to one lobule $(\times 400)$. Intralobular fibrosis, dilatation of acini and ducts. b Same lesion $(\times 1,800)$. Dilatation of ducts and flattening of their epithelial lining.

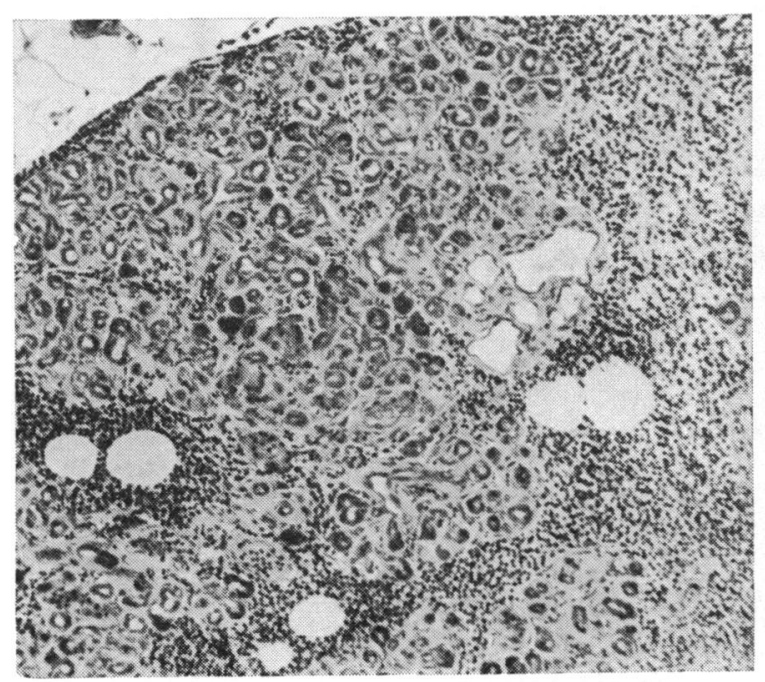

Fig. 3a.

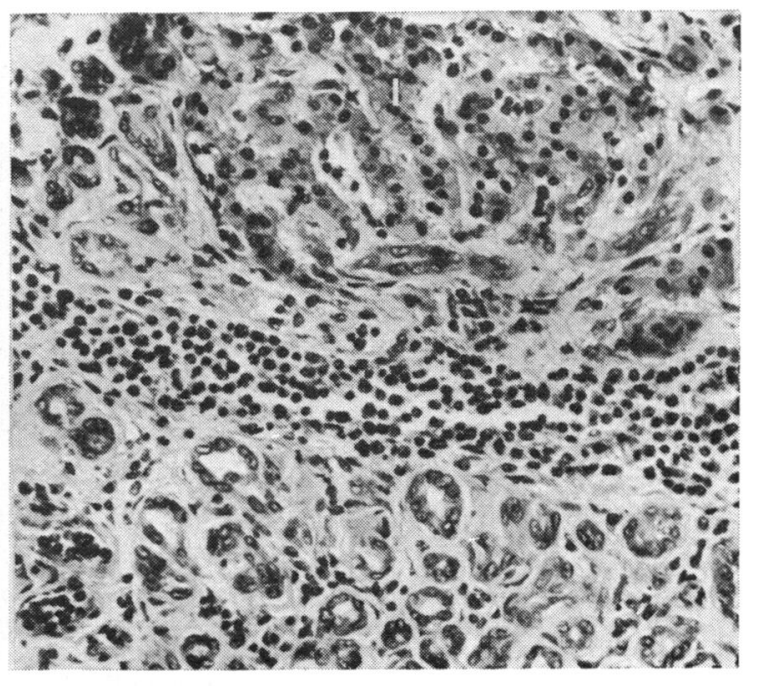

Fig. 3b.

Fig. 3 Pancreas of rat exposed to ethanol. Haematoxylin and eosin. a Pathological zone $(\times 400)$. Inflammatory sclerosis of perilobular connective tissue. Note dense infiltration with mononuclear cells, distension of acini and ducts, and perilobular and intralobular sclerosis. b Zone similar to a $(\times 900)$. Shows in addition an islet of Langerhans $(I)$. 


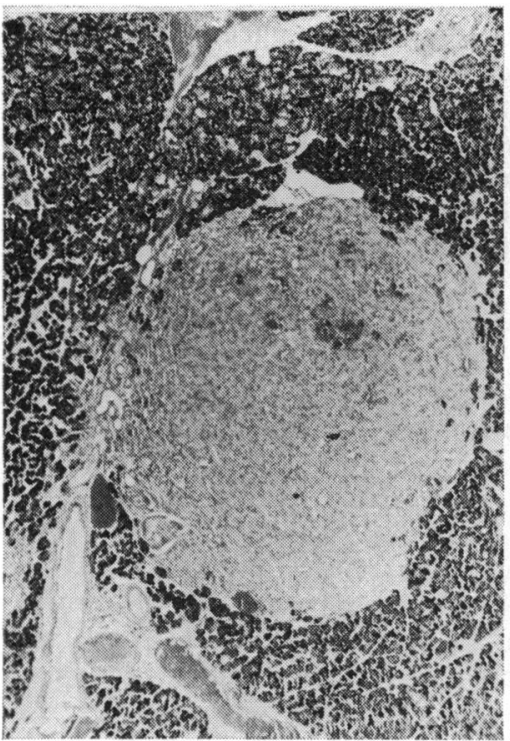

Fig. 4a.

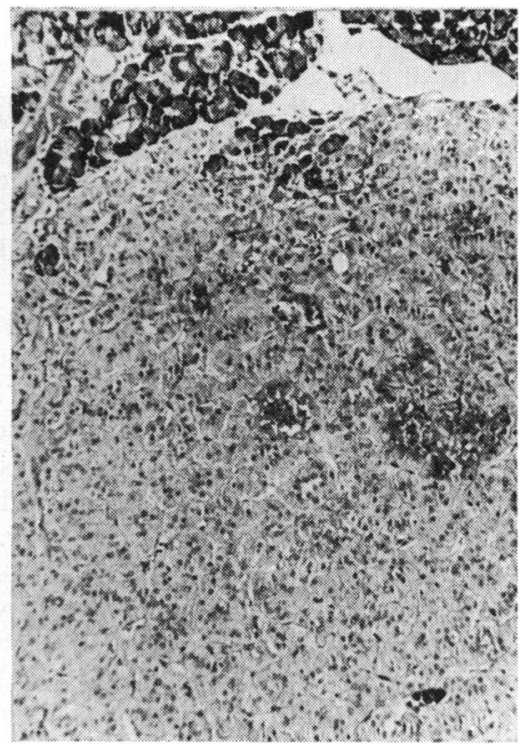

Fig. 4b.
Fig. 4 Pancreas of rat exposed to ethanol. Beta-cell adenomata of islet of Langerhans. Gomori's aldehyde fuchsin. a $\times 160$. b $\times 400$.

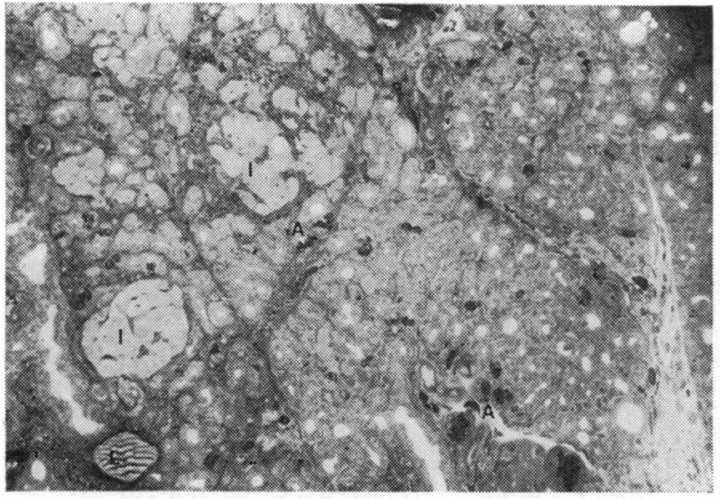

Fig. 5a.

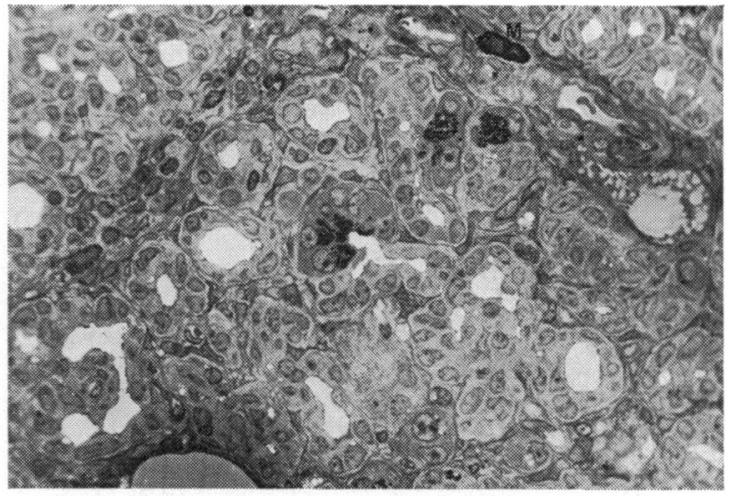

Fig. 5b.

Fig. 5 a General view of lobules undergoing ductal transformation. Toluidine blue $(\times 500) . A=$ residual acini; $I=$ islets of Langerhans; $L=$ fat cells; Embed = Epon. b Note, in centre, acinus with dilated lumen running into a bifurcating intercalary duct and, more peripherally, ductules with dilated lumina. Toluidine blue $(\times 1,600)$. $M=$ mastocyte; Embed = Epon.

The pathological changes of the exocrine tissue were in contrast to adjacent normal lobules. Multifocal lesions were rarely identical. Small lesions, possibly at the earlier stages, showed acinar loss and protein plugs; more developed a progressively interwoven inflammatory fibrosis (Fig. 4).

In most cases the endocrine pancreas appeared normal, but a characteristic type of hyperplasia of the islets of Langerhans was found in five animals, and adenomata of the islets, staining with Gomori's aldehyde fuchsin, and consisting mainly of beta cells, in four other animals (Fig. 4). Insular atrophy was present in one rat, the only one in which the entire exocrine pancreas was affected and in which the disease was probably at an advanced stage. The changes in the exocrine and endocrine parts of the gland appeared to be related topographically; the few hyperplastic islets observed lay in contiguity with damaged lobules.

Changes comparable to those noted in the paraffinembedded preparations were detected during the ultramicroscopic studies in the semithin sections 
from three ethanol rats and one control rat (Fig. 5a and b). In these pathological zones, as already seen in the light microscopy studies, most of the duct formations had the appearances characteristic of intercalary zones (Fig. 5b). Other zones corresponded (Fig. 5a and b) to acinar or, more often, to acinoductal segments in which the dilated lumina were lined by both acinar and ductal cells. Distension gave some of the ducts a cystic appearance and they were lined with flat endothelioid cells. These various structures were surrounded and separated from each other by fibrils of collagen, arranged loosely-or more rarely in bundles-and by a variety of cell types: fibroblasts, fat cells together with leucocytes, mastocytes, and histiocytes some of which contained large polymorphous inclusions of dense heterogeneous material. This gave a reaction with Perls' Prussian blue on light microscopy suggesting an association of iron with a phospholipoprotein complex.

The acinar cells of those acini which had preserved their integrity, although situated in the midst of pathological areas, or which were present in unaffected lobules, displayed no gross structural change (Fig. 6a and b). The ergastoplasm was abundant and occasionally somewhat dilated (Fig. 6a and b). Some Golgi cavities were also dilated, but only slightly. The mitochondria were normal. Zymogen granules were plentiful and were sometimes interspersed with a high proportion of prozymogen

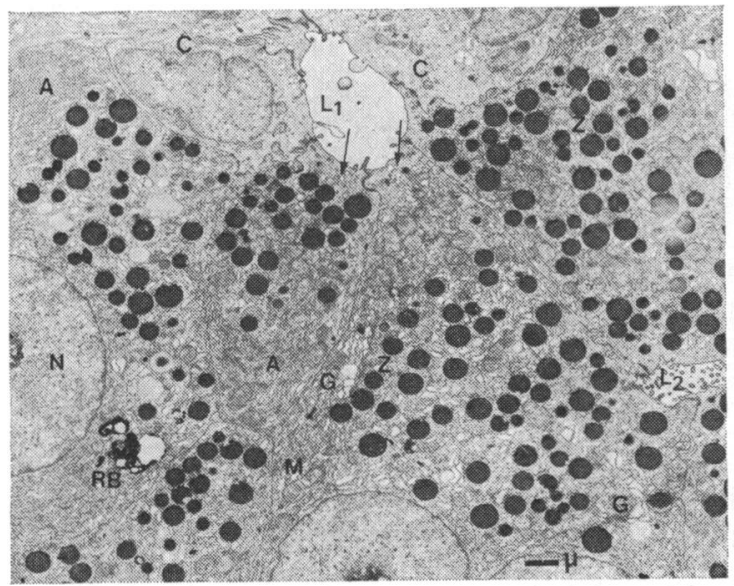

Fig. 6a.

Fig. 6 a Normal acinar cells $(A)$, normal duct cells $(C)$, and numerous zymogen granules $(Z)$. Uranyl acetate and lead citrate (originally $\times 5,700) . L_{1}=$ acinoduct lumen, slightly dilated. $L_{2}=$ acinar lumen with microvilli. $R B=$ residual bodies $\rightarrow:$ vesicles of smooth endoplasmic reticulum; $G=$ Golgi apparatus; $M=$ mitochondria; $N=$ nuclei; Fix $=\mathrm{OsO}_{4} ;$ Embed $=$ Epon. b Acinoductal segment with dilated lumen $(L A)$. Uranyl acetate and lead citrate (originally $\times 7,000)$. The content is of low cell density and has a faintly fibrillary appearance. $A=$ acinar cells with moderate content of zymogen granules; $\rightarrow=$ vesicles of smooth endoplasmic reticulum; $G=$ Golgi apparatus; $M=$ mitochondria; $\mathrm{C}=$ duct cells; $\mathrm{L}=$ lipid inclusion; $\mathrm{Fix}=\mathrm{OsO}_{4} ;$ Embed $=$ Epon. 
intact areas of pancreatic parenchyma, constituted the predominant element in the pathological areas. Their shape was pyramidal when they lined narrow lumina, flattened cuboidal or endothelioid when they surrounded the broad, sometimes cyst-like cavities. In many rows of microvilli or of swollen club-shaped cytoplasmic protrusions projected from the apical poles, and the lateral borders were indented by deep folds of the plasma membranes. The duct cells generally differed from the acinar cells in having a clear matrix and simple cytoplasmic organization of a few small mitochondria, the ergastoplasm being reduced to a few small granular cisterns and scattered polymorphous bodies, with

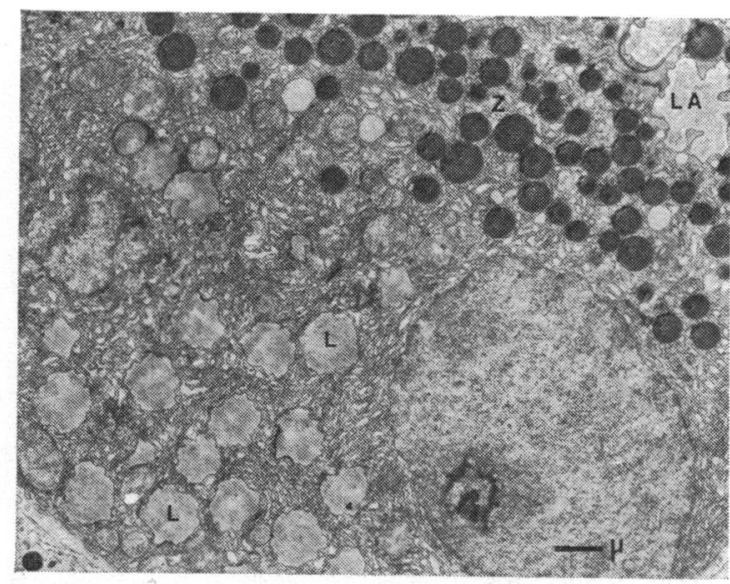

Fig. 7a.

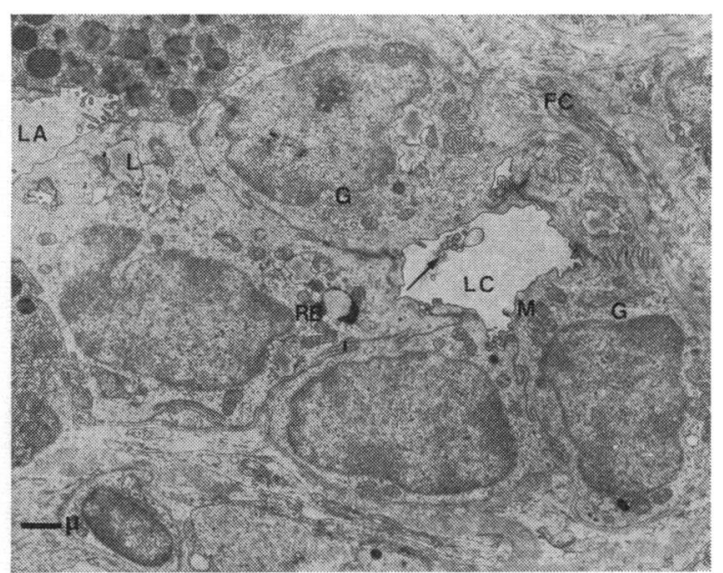

Fig. $7 \mathrm{~b}$.

Fig. 7 a Acinar cell containing excess lipid $(L)$ and numerous zymogen granules $(Z)$. Uranyl acetate and lead citrate (originally $\times 8,000$ ). LA = lumen of acinus with dense heterogeneous content; Fix $=\mathrm{OsO}_{4} ;$ Embed $=$ Epon. b Normal intercalary duct. Uranyl acetate and lead citrate $(\times 6,800) . L C=$ duct lumen with microvilli in section (arrow); $L A=$ acinoduct lumen containing dense heterogeneous material; $G=$ Golgi apparatus; $M=$ mitochondria; $L=$ lipid inclusions; $R B=$ residual body; $F C=$ collagen fibrils; $F i x=\mathrm{OsO}_{4} ;$ Embed $=$ Epon.

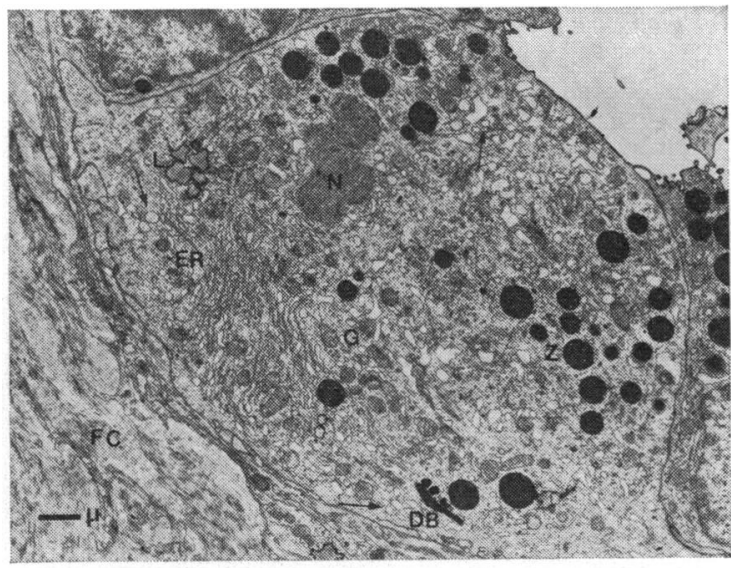

Fig. 8a.

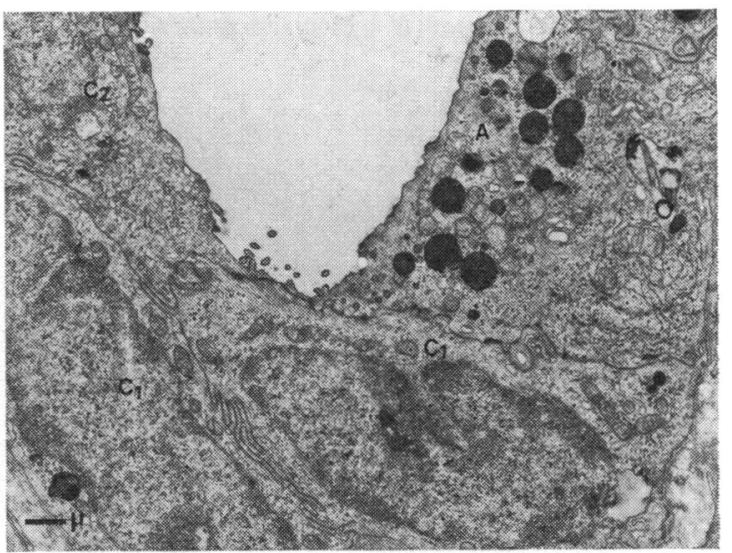

Fig. 8b.

Fig. 8 a Atrophic acinar cell in the wall of a dilated acinus. Uranyl acetate and lead citrate (originally $\times 7,000)$. The ergastoplasm $(E R)$ is relatively scarce and contains vacuolated cisterns (arrow). The Golgi apparatus (G) is reduced and the zymogen granules $(Z)$ are few. $L=$ lipid inclusions; $D B=$ dense body; $N=$ nucleus;

$\mathrm{FC}=$ collagen fibrils; Fix $=\mathrm{OsO}_{4} ;$ Embed $=$ Epon. b Dilated acinoduct segment. Uranyl acetate and lead citrate (originally $\times$ 6,800). $A=$ small acinar cell; all its components are reduced; $C_{1}=$ duct cells; $C_{2}=$ cell in appearance like a duct type (in the development of its ergastoplasm it resembles cells such as $A$ ); Fix $=\mathrm{OsO}_{4} ; \mathrm{Embed}^{2}=\mathrm{Epon}_{\text {. }}$ 
poorly developed Golgi apparatus. Though these were features of the majority of the duct cells, a minority had abundant smooth endoplasmic reticulum containing numerous vacuoles, a hypertrophied Golgi apparatus, in some cases even an increased number of mitochondria. Dense bodies and heterogeneous or lipid inclusions were more numerous than under normal conditions, and the outlines of the cell nuclei were often irregular and deeply notched.

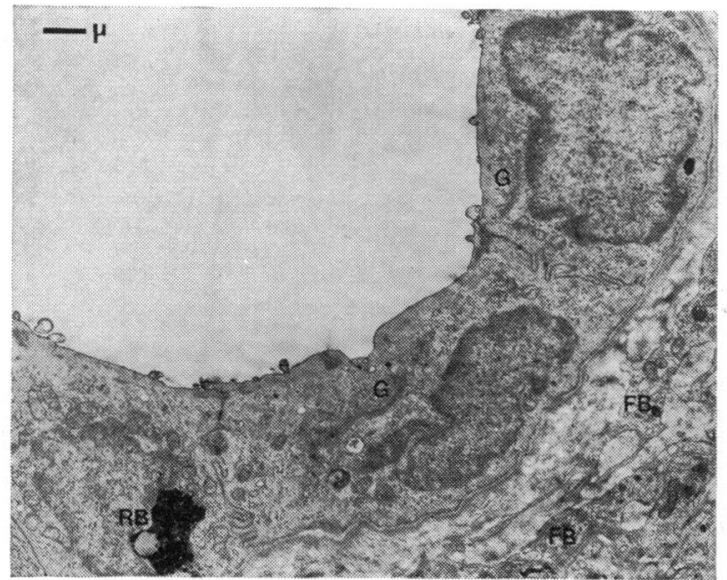

Fig. 9a.
The walls of the dilated ducts and of the cystic cavities were formed of flat endothelioid cells (Fig. $10 \mathrm{a}$ and $\mathrm{b}$ ), broadly spread out in an overlapping arrangement like the tiles on a roof. Some had a highly developed endoplasmic reticulum, others a rich ergastoplasm which suggested an acinar origin (Fig. 10).

The lumina of certain acini and ducts contained a flocculent fibrillary sustance of low electron density. Other ducts contained accumulations of osmiophilic

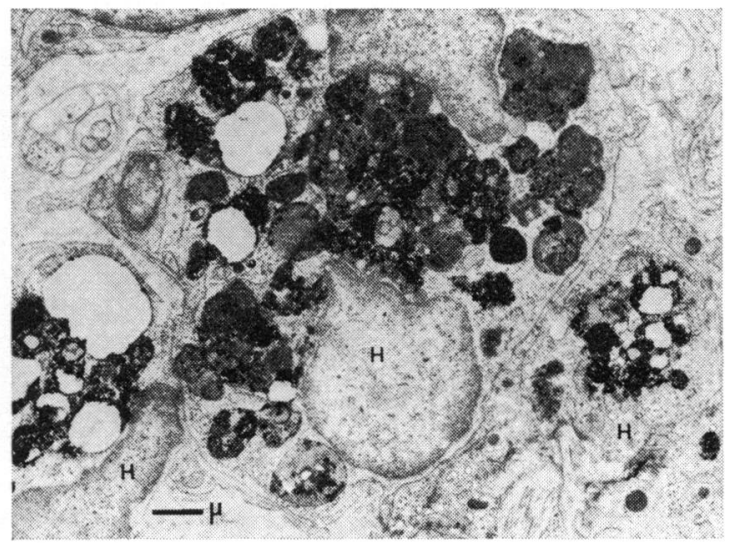

Fig. 9b.

Fig. 9 a Wall of a dilated duct with flattened cuboidal cells. Uranyl acetate and lead citrate (originally $\times 6,800$ ). $\boldsymbol{G}=$ Golgi apparatus (in general well developed); $\mathrm{RB}=$ residual body; $\mathrm{FB}=$ fibroblasts; Fix $=\mathrm{OsO}_{4} ; \mathrm{Embed}=$ Epon. $\mathrm{b}$ The interstitial spaces in the areas of duct alteration are infiltrated by large, heterogeneous osmiophilic inclusions in histiocytes $(\mathrm{H})$. Uranyl acetate and lead citrate (originally $\times 8,800$ ). Fix $=\mathrm{OsO}_{4} ;$ Embed $=$ Epon.

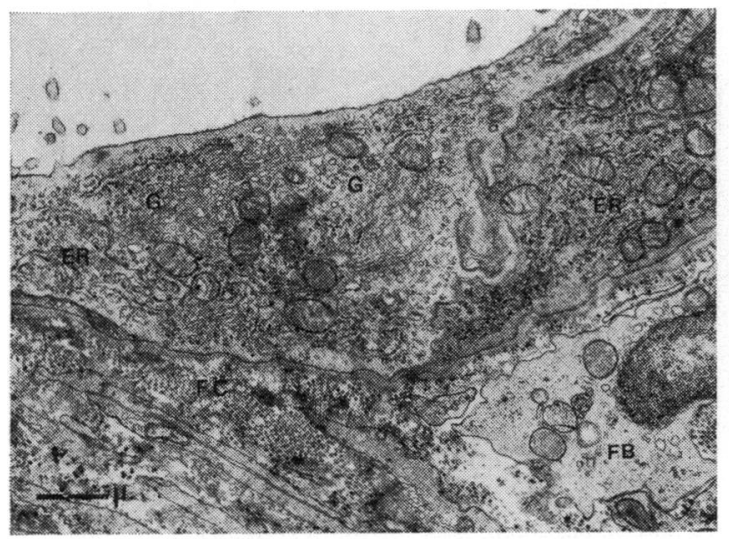

Fig. 10a.

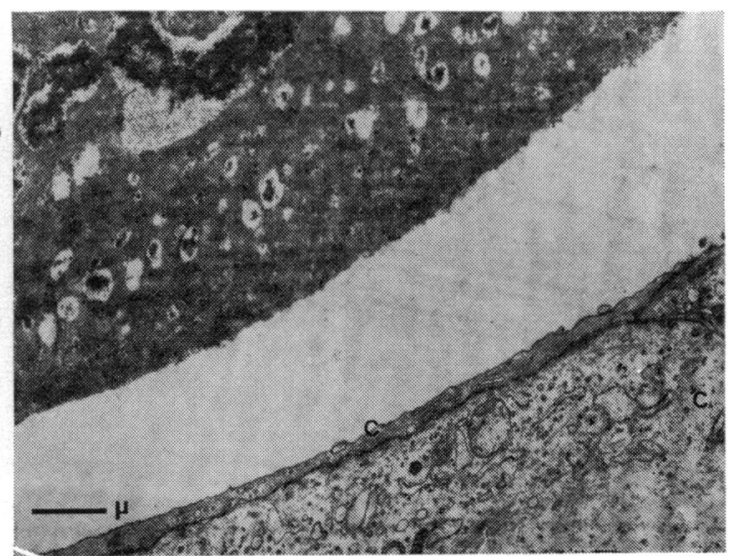

Fig. 10b.

Fig. 10 a Mural cells of a cystic cavity. The abundant Golgi apparatus $(G)$ and highly developed ergastoplasm (ER) suggest that these cells are of acinar nature. Uranyl acetate and lead citrate (originally $\times 12,700) . F B=$ fibroblasts; $F C=$ collagen fibrils; $\mathrm{Fix}=\mathrm{OsO}_{4} ;$ Embed $=$ Epon. b Heterogeneous osmiophilic concretion in a dilated duct . Uranyl acetate and lead citrate (originally $\times 12,700) . \mathrm{C}=$ flattened mural cells; Fix $=\mathrm{OsO}_{4} ;$ Embed $=$ Epon. 
material, heterogeneous in appearance and comparable to the protein plugs noted on light microscopy (Fig. 10b).

In summary, apart from the lesions the pancreatic tissue showed no severe or characteristic ultrastructural changes, although polymorphous inclusions of residual body type and lipid deposits were more numerous than in control specimens. In the areas undergoing ductal transformation cells of ductal or centroacinar type predominated. In addition to residual bodies and occasional lipid deposits, some of these cells displayed hypertrophy of the endoplasmic reticulum suggestive of a hyperactive state. The cells of acinar type also present in the ducts were more atrophic than degenerative. Their dimensions were reduced and their cytoplasmic components underdeveloped and in extreme cases it was difficult to distinguish them from duct cells, a fact which provides some justification for the term 'acinoductal dedifferentiation'. True duct cells predominate in the dilated ducts seen in the pathological foci, either a relative increase due to progressive disappearance of the acinar cells, or more likely representing a true proliferation.

\section{Discussion}

\section{ACUTE ETHANOL INTOXICATION}

Rats tolerated ethanol well in a dosage of up to $3 \mathrm{~g} / \mathrm{kg}$ on three consecutive days. Doses higher than this caused death, but the only constant pathological changes observed in the pancreas was venous congestion which was always present in even greater degree in the liver and kidney. Whatever may be the cause of death, it does not seem to involve the pancreas. These findings do not accord with those of Trémolieres et al (1963); however, intraperitoneal injection of ethanol, by which these workers produced pancreatic lesions, may act simply as a nonspecific irritant, since Alvizouri and Borunda (1967) have demonstrated that irritant intraperitoneal injections are liable to cause acute pancreatitis.

\section{CHRONIC ETHANOL INTOXICATION}

The lesions produced in rats by chronic ethanol administration have points in common (cf, Figs. 1 and 2) with those of human chronic pancreatitis, a disease which is often, although not invariably caused by alcohol (Sarles et al, 1965). In man, as in the rat, the lesions are segmental and affected lobules lie side by side with normal lobules, at least in the early stages of intoxication (Fig. 2). The fundamental changes in the pathological foci are common to both species. These are protein plugs, some of which are calcified, in the ducts; reduction of acinar cells, which are replaced by dilated ducts; and sclerosis. The lesions seen under the electron microscope are less exactly superimposable. Apart from the presence of polymorphous inclusions, always moderate in number, degenerative changes in the acinar cells are less pronounced in rats than in man. The shorter evolution of the lesions in rats has to be taken into account in interpreting these observations. It is perhaps significant that one of the 12 control rats had a pancreatic lesion identical to that found in the ethanol-intoxicated animals. Kendrey and Roe (1969) described similar lesions in chronic pancreatitis occurring spontaneously in the rat, and Wexler (1970) in repeatedly bred male and female rats. Limited acinoductal lesions occur in normal man also, and it may be that the role of alcohol is to aggravate or unmask lesions which usually remain latent (Sarles et al, 1965).

The toxic effect of ethanol on the rat pancreas has been interpreted by Darle et al (1970) as a cellular autophagia evidenced by abundant foci of cytoplasmic degradation (lysosomes). Our findings do not support this interpretation. Abundance of lysosomes, moreover, is as much a physiological as a pathological phenomenon, since it is seen after pancreozymin stimulation (Hermodsson, 1965).

It is not relevant to our experiments that ethanol causes increased tone of the sphincter of the hepatopancreatic ampulla (sphincter of Oddi) with or without pancreatic hypersecretion, as has been shown by Menguy et al (1958) and Pirola and Davis (1967), since this sphincter is not present in rats.

The work of Sarles and his associates (1965 and 1970) suggests that the primary factor in chronic calcifying pancreatitis in man is precipitation of a protein material in the pancreatic ducts; this leads to the formation of protein plugs which later calcify to form calculi. The dilatation and the lesions of the acini and the ducts appear to be secondary to obstruction by these 'plugs'. Similar protein precipitates are often seen in the pancreatic juice of patients with chronic calcifying pancreatitis; their appearance in the juice coincides with the disappearance of certain enzyme bands on polyacrylamide-gel electrophoresis (Figarella, Marteau, and Sarles, 1969). Protein plugs, some of them calcified, were constantly found in the ducts of our rats with pancreatic lesions. They were also noted in one animal in which the pancreas was intact and this suggests that they may precede the lesions. The pancreatic juice of our ethanol-treated animals was rich in protein and showed spontaneous protein precipitation. Sarles et al (1970) showed that consumption of ethanol for two months by rats fed on high fat protein diets led to increased concentration of enzymatic proteins in the zymogen granules. 
These observations should be considered in the light of two other findings.

(1) Protein concentrations and protein precipitates similar to those noted in the ethanol rats of the present series were found in the pancreatic juice of a 1-year-old rat which had drunk water only.

(2) Precipitates are encountered, although less frequently, in pancreatic juices of low protein concentration; perhaps, therefore, concentration is not the only factor concerned in precipitation, or perhaps precipitated proteins escape measurement.

It may be that alcohol does no more than increase the protein concentration in the pancreatic secretion and promote duct obstruction through precipitation of these proteins. This is a phenomenon which may, very rarely, occur spontaneously. Thus local pancreatic lesions could therefore reasonably be explained as the result of raised pressure in areas drained by ducts blocked by protein precipitate.

We have seen that beta-cell adenomata of the islets of Langerhans were noted in four of the animals treated with ethanol. This contrasts with hypoplasia of the exocrine tissue observed in the only animal in which the destruction of exocrine tissue was intense and diffuse. The significance of these findings is not clear.

Ethanol pancreatitis in rats appears between the 20th and 30th month of exposure, by which time half the animals admitted to the experiment have died of old age. The average age of appearance of chronic alcoholic pancreatitis in man is 38 , and of alcoholic hepatic cirrhosis over 50 (Martini and Bode, 1970). This suggests that failure hitherto to produce experimental alcoholic cirrhosis in rats might be because their life span is shorter than the time required for this hepatic cirrhosis to develop.

\section{References}

Alvizouri, M., and Borunda, L. (1967). 'DL-ethionine' in prevention of experimental pancreatitis in the rat. Amer. J. dig. Dis., 12, 1017-1024.

Cueto, J., Tajen, N., and Zimmermann, B. (1967). Studies of experimental alcoholic pancreatitis in the dog. Surgery, 62, 159-166.

Darle, N., Ekholm, R., and Edlund, Y. (1970). Ultrastructure of the rat exocrine pancreas after long term intake of ethanol. Gastroenterology, 58, 62-72.

Decloitre, F., and Lowy, R. (1963). Modifications des constituants phosphorés hépatiques et pancréatiques du rat par injection d'ethanol. C.R. Soc. Biol. (Paris), 157, 46-51.

Figarella, C., Marteau, C., and Sarles, H. (1969). Etude des sucs pancréatiques humains normaux et pathologiques par électrophorèse en disque. In VIIIth International Congress of Gastro- enterology, edited by Pr. Gregor and Dr Rield, pp. 1199-1201. Schattauer, Stuttgart, and New York.

Goslin, J., Hong, S. S., Magee, D. F., and White, T. T. (1965). Relationship between diet, ethyl alcohol consumption and some activities of the exocrine pancreas in rats. Arch. int. Pharmacodyn., 157, 462-469.

Hermodsson, L. H. (1965). The Ultrastructure of Exocrine Pancreas Cells as Related to Secretory Activity, pp. 86-117. Almqvist and Wiksells, Uppsala.

Kendrey, G., and Roe, E. J. C. (1969). Histopathological changes in the pancreas of laboratory rats. Lab. Anim., 3, 207-220.

Lowry, O. H., Rosebrough, N. J., Farr, A. L., and Randall, R. J. (1951). Protein measurement with the folin phenol reagent. $J$. biol. Chem., 193, 265-275.

Luft, J. H. (1961). Improvements in epoxy resin embedding methods. J. biophys. biochem. Cytol., 9, 409-414.

Martini, G. A., and Bode, C. (1970). Zur Epidemiologie der Lebercirrhose. Der Internist (Berl.), 11, 84-93.

Menguy, R. B., Hallenbeck, G. A., Bollman, J. L., and Grindlay, J. H. (1958). Intraductal pressures and sphincteric resistance in canine pancreatic biliary ducts after various stimuli. Surg. Gynec. Obstet., 106, 306-320.

Millonig, G. (1961). Advantages of a phosphate buffer for OsO, solutions in fixation. J. appl. Physics, 32, 1637.

Orrego-Matte, H., Navia, E., Feres, A., and Costamaillere, L. (1969). Ethanol ingestion on and incorporation of saP into phospholipids of pancreas in the rat. Gastroenterology, 56, 280-285.

Pilora, R. C., and Davis, A. E. (1967). The role of ethyl alcohol in the aetiology of pancreatitis. Gut, 8, 526 .

Reynolds, E. S. (1963). The use of lead citrate at high $\mathrm{pH}$ as an electron opaque stain in electron microscopy. J. Cell. Biol., 17, 208-212.

Sardesai, V. M., and Orten, J. M. (1968). Effect of prolonged alcohol consumption in rats on pancreatic protein synthesis. $J$. Nutr., 96, 241-246.

Sarles, H. (1970). Étiopathogénie des pancréatites chroniques. Schweiz. med. Wschr., 100, 1190-1194.

Sarles, H., and Figarella, C. (1967). Étude de l'action de l'éthanol et des graisses alimentaires sur le pancréas du rat. I.Variations des enzymes pancréatiques (lipase, amylase, chymotrypsinogène, trypsinogène). Path. et Biol., 15, 725-731.

Sarles, H., Figarella, C., and Clemente, F. (1970). The interaction of ethanol, dietary lipids and proteins on the rat pancreas. I. Pancreatic enzymes. Digestion, 4, 13-22.

Sarles, H., Sarles, J. C., Camatte, R., Muratore, R., Gaini, M., Guien, C., Pastor, J., and Le Roy, F. (1965). Observations on 205 confirmed cases of acute pancreatitis, recurring pancreatitis, and chronic pancreatitis. Gut, 6, 545-559.

Siegel, S. (1956). Nonparametric Statistics for the Behavioural Science, p. 116. McGraw-Hill, New York.

Tasso, F. (1967). Étude ultrastructurale du pancréas dans 8 cas de pancréatites chroniques. Ann. Anat. path., 12, 343-372.

Tasso, F., Clop, J., and Sarles, H. (1970). The interaction of ethanol, dietary lipids and proteins on the rat pancreas. II/Ultrastructural study. Digestion, 4, 23-34.

Trémolieres, J., Carre, L., Scheggia, E., Potet, F., and Martin, E. (1963). Pancréatites nécrosantes et hémorragiques par administration d'éthanol á doses toxiques et répétées au rat. $C$. $R$. Soc. Biol. (Paris), 157, 1189-1190.

Tsuzuki, T., Watanabe, N., and Thal, A. P. (1965). The effect of obstruction of the pancreatic duct and acute alcoholism on pancreatic protein synthesis. Surgery, 57, 724-729.

Watson, M. L. (1958). Staining of tissue sections for electron microscopy with heavy metals. II/Application of solutions containing lead and barium. J. biophys. biochem. Cytol., 4, 727 . 730.

Wexler B. C. (1970). Arteriosclerosis of the pancreas and changes in the islets of Langherhans of repeatedly bred rats. Brit. J. exp. Path., 51, 107-113. 